\title{
Effects of Dietary Ingredients on Function and Expression of P-Glycoprotein in Human Intestinal Epithelial Cells
}

\author{
Takashi Okura, ${ }^{a, 1)}$ Michiko Ibe, ${ }^{a}$ Keizo Umegaki, ${ }^{b}$ Kazumasa Shinozuka, ${ }^{c}$ and Shizuo Yamada ${ }^{*}, a$ \\ ${ }^{a}$ Department of Pharmacokinetics and Pharmacodynamics and Global Center of Excellence (COE), School of \\ Pharmaceutical Sciences, University of Shizuoka; 52-1 Yada, Suruga-ku, Shizuoka 422-8526, Japan: ${ }^{b}$ Center of \\ Information, National Institute of Health and Nutrition; 1-23-1 Toyama, Shinjuku-ku, Tokyo 162-8636, Japan: and \\ ${ }^{c}$ Department of Pharmacology, Faculty of Pharmaceutical Sciences, Mukogawa Women's University; 11-68 Koshien \\ Kyuban-cho, Nishinomiya, Hyogo 663-8179, Japan.
}

Received November 3, 2009; accepted November 24, 2009; published online November 30, 2009

The present study was conducted to investigate the functional and transcriptional modulation of P-glycoprotein (MDR-1) by several dietary ingredients (piperine, capsaicin, daidzein, genistein, sesamin, curcumin, taurine) in vinblastine-resistant colon carcinoma LS-180 cells (LS-180V cells). The amount of rhodamine 123 accumulated in LS-180V cells was significantly increased by capsaicin, piperine and sesamin, whereas it was significantly reduced by daidzein and genistein which stimulated the efflux of rhodamine 123 . These results suggest that the P-glycoprotein-mediated efflux is inhibited by piperine, capsaicin and sesamin and stimulated by daidzein and genistein. The concurrent addition of piperine and capsaicin seemed to inhibit synergistically the P-glycoproteinmediated efflux. Pretreatment with sesamin for $48 \mathrm{~h}$ caused a significant increase in MDR1 mRNA expression without a significant effect on the expression of P-glycoprotein or accumulation of rhodamine 123. Similar pretreatment with other ingredients had little effect on the expression of MDR1 mRNA or P-glycoprotein, suggesting that they do not cause transcriptional modulation of P-glycoprotein. Piperine, genistein and curcumin have been suggested to stimulate P-glycoprotein-mediated efflux without increasing P-glycoprotein expression. In LS$180 \mathrm{~V}$ cells, significant increases in mRNA levels of multi-drug resistance associated protein 1 (MRP1) or MRP3 were observed on pretreatment with capsaicin, daidzein, piperine and sesamin. In conclusion, our results suggest that P-glycoprotein-mediated efflux is significantly affected by dietary ingredients. Also, capsaicin, daidzein, piperine and sesamin increased significantly the mRNA expression of MRP1 or MRP3. Thus, the present study provides further evidence that repeated exposure to dietary ingredients can cause drug-food interactions by affecting the function and mRNA expression of intestinal transporters such as P-glycoprotein.

Key words dietary ingredient; P-glycoprotein; intestinal epithelia

Drug-food interactions are increasingly recognized as having potential clinical implications. ${ }^{2,3)}$ Recent investigations have shown that several dietary ingredients modulate not only drug-metabolizing enzymes but also drug transporters in intestinal epithelial cells ${ }^{3,4}$ which functionally express ATP-binding cassette transporters such as P-glycoprotein and multi-drug resistance associated proteins (MRPs). ${ }^{5,6)}$ For example, piperine, a major constituent of black pepper, and capsaicin, a pungent component of chili pepper, have been shown to inhibit P-glycoprotein-mediated drug efflux. ${ }^{7,8)}$ Also, curcumin, a yellow pigment of turmeric, has been reported to modulate P-glycoprotein expression. ${ }^{9,10)}$ Thus, modulation of both the function and expression of intestinal transporters by dietary ingredients may affect the uptake of their substrates.

The current study was undertaken to investigate the effects of piperine, capsaicin and curcumin, daidzein (a soybean isoflavone), genistein (a soybean isoflavone), sesamin (a sesame lignan) and taurine (an amino acid in seafood) (Fig. 1) on the function and expression of P-glycoprotein. Pharmacokinetic and pharmacodynamic interactions involving these dietary ingredients, which are frequently consumed as dietary supplements or health foods, may occur in patients receiving drug therapy. In the present study, we used vinblastine-resistant colon carcinoma LS-180 cells (LS-180V cells), an intestinal model for the analysis of both transcriptional and functional changes of transporters such as P-glycoprotein. ${ }^{11,12)}$

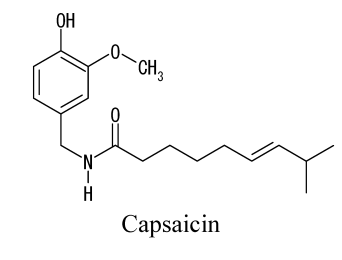<smiles>O=c1c(-c2ccc(O)cc2)coc2cc(O)ccc12</smiles><smiles>O=c1c(-c2ccc(O)cc2)coc2cc(O)cc(O)c12</smiles>

Daidzein<smiles>O=C(/C=C/C=C/c1ccc2c(c1)OCO2)N1CCCCC1</smiles>

Piperine

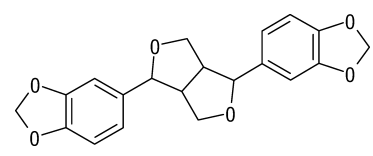

Sesamin

Genistein

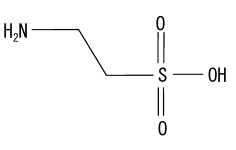

Taurine<smiles>COc1cc(/C=C/C(=O)CC(=O)/C=C/c2ccc(O)c(O)c2)ccc1O</smiles>

Curcumin

Fig. 1. Chemical Structure of Capsaicin, Piperine, Daidzein, Genistein, Sesamin, Taurine and Curcumin 


\section{MATERIALS AND METHODS}

Materials LS-180 cells were obtained from American Type Culture Collection (Manassas, VA, U.S.A.) and maintained in Dulbecco's modified Eagle's medium (DMEM) supplemented with $10 \%$ fetal bovine serum, $1 \%$ nonessential amino acids, 50 units $/ \mathrm{ml}$ penicillin, and $0.05 \mathrm{mg} / \mathrm{ml}$ streptomycin. LS-180V cells were derived from LS-180 cells by stepwise selection in vinblastine and maintained in $4 \mathrm{ng} / \mathrm{ml}$ vinblastine. ${ }^{11)}$ All chemicals were purchased from commercial sources.

Uptake and Efflux Experiments To evaluate P-glycoprotein-mediated efflux, the cellular accumulation and efflux of rhodamine 123 were determined as reported. ${ }^{13,14)}$ LS$180 \mathrm{~V}$ cells were seeded at $5 \times 10^{5}$ cells $/ \mathrm{cm}^{2}$ on multiwell plates (BIOCOAT ${ }^{\circledR}$ Collagen I Cellware 24-Well Plate, Becton Dickinson Bioscience, Bedford, MA, U.S.A.) and grown for $4 \mathrm{~d}$. Cells were washed with $1 \mathrm{ml}$ of Hanks balanced salt solution (HBSS) three times, and pre-incubated in HBSS at $37^{\circ} \mathrm{C}$ for $30 \mathrm{~min}$. Cells were incubated with rhodamine 123 $(10 \mu \mathrm{M})$ in $\mathrm{HBSS}$ at $37^{\circ} \mathrm{C}$ for $60 \mathrm{~min}$ in the absence and presence of capsaicin $(1-100 \mu \mathrm{M})$, piperine $(1-300 \mu \mathrm{M})$, sesamin $(1-100 \mu \mathrm{M})$, daidzein $(1-100 \mu \mathrm{M})$, genistein $(1-$ $100 \mu \mathrm{M})$, curcumin $(1,10 \mu \mathrm{M})$, taurine $(1-100 \mu \mathrm{M})$ or cyclosporin A $(17 \mu \mathrm{M})$. The cells were then washed with icecold phosphate-buffered saline (PBS) three times. After cell solubilization, the fluorescence intensity of rhodamine 123 was measured by a fluorescence plate reader with excitation at $485 \mathrm{~nm}$ and emission at $535 \mathrm{~nm}$. The protein content was measured with a BCA protein assay kit (Pierce Chemical Co., Rockford, IL, U.S.A.).

To examine the effects of pretreatment, capsaicin $(1-100$ $\mu \mathrm{M})$, piperine $(1-300 \mu \mathrm{M})$, sesamin $(1-100 \mu \mathrm{M})$, daidzein $(1-100 \mu \mathrm{M})$, genistein $(1,10 \mu \mathrm{M})$, curcumin $(1,10 \mu \mathrm{M})$, taurine $(1-100 \mu \mathrm{M})$ or rifampicin $(10 \mu \mathrm{M})$ was added to the cells $2 \mathrm{~d}$ after seeding, and the culture was continued for $48 \mathrm{~h}$. Before the uptake experiments, the cells were washed three times and incubated for $0.5 \mathrm{~h}$ with HBSS. The accumulation of rhodamine $123(10 \mu \mathrm{M}$, for $60 \mathrm{~min})$ was measured as described above.

In the efflux experiments, cells were washed with HBSS three times and pre-incubated in HBSS at $37^{\circ} \mathrm{C}$ for $30 \mathrm{~min}$. Cells were incubated with rhodamine $123(10 \mu \mathrm{M})$ for $90 \mathrm{~min}$ (loading time) at $37^{\circ} \mathrm{C}$. After the loading, the medium containing rhodamine 123 was immediately removed, and the cells were incubated with $\mathrm{HBSS}$ for $90 \mathrm{~min}$ at $37^{\circ} \mathrm{C}$ in the absence and presence of daidzein $(100 \mu \mathrm{M})$, genistein $(100$ $\mu \mathrm{M})$ or cyclosporin A $(17 \mu \mathrm{M})$. The cells were washed with ice-cold PBS and solubilized, then the fluorescence intensity of rhodamine 123 was measured as described above.

Quantitative Real-Time Polymerase Chain Reaction (PCR) LS-180V cells were seeded at $5 \times 10^{5}$ cells $/ \mathrm{cm}^{2}$ on multiwell dishes (BIOCOAT ${ }^{\circledR}$ Collagen I Cellware 6-Well Plate, Becton Dickinson Bioscience) and grown as described above. Two days after seeding, cells were treated with capsaicin $(100 \mu \mathrm{M})$, piperine $(300 \mu \mathrm{M})$, sesamin $(10 \mu \mathrm{M})$, daidzein $(100 \mu \mathrm{M})$, genistein $(100 \mu \mathrm{M})$, curcumin $(10 \mu \mathrm{M})$, taurine $(100 \mu \mathrm{M})$ or rifampicin $(10 \mu \mathrm{M})$ for $48 \mathrm{~h}$. Total RNA was isolated from the treated and untreated cells using an RNeasy minikit (Qiagen, Valencia, CA, U.S.A.). The RNA was reverse-transcribed (Superscript reverse transcriptase) using oligo $(\mathrm{dT})_{12-18}$ primers. Specific primers were used for human MDR1 (sense: 5'-GCT CCT GAC TAT GCC AAA GC-3'; antisense: 5'-ATT AGG CCT TCC GTG CTG TA3'), MRP1 (sense: 5'-CAT GAA GGC CAT CGG ACT CT3'; antisense: 5'-CAG GTC CAC GTG CAG ACA G-3'), MRP2 (sense: 5'-CTC ATT CAG ACG ACC ATC CA-3'; antisense: 5'-GGC TGC CGC ACT CTA TAA TC-3'), MRP3 (sense: 5'-GAC TTC CAG TGC TCA GAG GG-3' antisense: 5'-TGT CAG TCT CCA GGT CGA TG-3') and $\beta$-actin (sense: 5'-AAG AGA TGG CCA CGG CTG CT-3'; antisense: 5 '-TCC TTC TGC ATC CTG TCG GCA-3'). ${ }^{15)}$ The quantitative PCR assay was performed using a GeneAmp 5700 detection system (Applied Biosystems, Foster City, CA, U.S.A.) and QuantiTect SYBR green PCR master mix (Qiagen).

Western Blotting P-Glycoprotein expression at the protein level was determined by Western blotting. ${ }^{16)}$ LS-180V cells were seeded at $5 \times 10^{5}$ cells $/ \mathrm{cm}^{2}$ on multiwell dishes (BIOCOAT $^{\circledR}$ Collagen I Cellware 6-Well Plate, Becton Dickinson Bioscience) and grown as described above. Two days after seeding, cells were treated with capsaicin $(100 \mu \mathrm{M})$, sesamin $(10 \mu \mathrm{M})$, daidzein $(100 \mu \mathrm{M})$, genistein $(100 \mu \mathrm{M})$ or rifampicin $(10 \mu \mathrm{M})$ for $48 \mathrm{~h}$. The cells were harvested by scraping into homogenization buffer (PBS containing $2 \mathrm{~mm}$ phenylmethylsulfonyl fluoride, $0.8 \mu \mathrm{M}$ aprotinin, $20 \mu \mathrm{M}$ leupeptin, $40 \mu \mathrm{M}$ bestatin, and $15 \mu \mathrm{M}$ pepstatin A) and pelleted by centrifugation. The cells were homogenized in the homogenization buffer by sonication. The homogenate was centrifuged at $100000 \mathrm{~g}$ for $1 \mathrm{~h}$ at $4{ }^{\circ} \mathrm{C}$, and the resulting pellet was suspended in the homogenization buffer. The protein content of the membrane preparations was determined as described above. The samples $(60 \mu \mathrm{g}$ protein) were separated on a $7.5 \%$ sodium dodecyl sulfate-polyacrylamide gel and transferred electrophoretically onto a nitrocellulose membrane, which was blocked in Tris-buffered saline (TBS)Tween $0.1 \%$ containing $7.5 \%$ defatted milk for $1 \mathrm{~h}$ and incubated with anti-P-glycoprotein antibody (C219, 1:750) in the same solution overnight at $4{ }^{\circ} \mathrm{C}$. The membrane was then washed with TBS-Tween, incubated with a horseradish peroxidase-linked goat anti-mouse immunoglobulin G (IgG) antibody $(1: 2000)$ in TBS-Tween for $1 \mathrm{~h}$, and rinsed with TBS-Tween. The membrane was exposed to the Amersham ECL detection agent, and bands were quantitated by densitometric analysis.

Data Analysis The significance of differences was evaluated with Student's $t$-test and with a one-way analysis of variance followed by Dunnett's test for single and multiple comparisons, respectively. The criterion of significance was $p<0.05$.

\section{RESULTS}

Effects of Dietary Ingredients on the Accumulation and Efflux of Rhodamine 123 in LS-180V Cells The accumulation of rhodamine 123 in LS-180V cells was significantly (4.5-fold) increased in the presence of cyclosporin A $(17 \mu \mathrm{M})$ (Table 1), indicating that P-glycoprotein operates as an efflux transporter in LS-180V cells. Rhodamine 123 levels in LS-180V cells rose significantly in the presence of capsaicin $(100 \mu \mathrm{M})$, piperine $(30-300 \mu \mathrm{M})$ and sesamin $(100 \mu \mathrm{M})$, the respective increases being $1.4,1.5-2.3$ and 2.2-fold (Table 
Table 1. Effects of Dietary Ingredients on Rhodamine 123's Accumulation in LS-180V Cells

\begin{tabular}{|c|c|c|}
\hline & $\begin{array}{l}\text { Concentration } \\
\qquad(\mu \mathrm{M})\end{array}$ & $\begin{array}{l}\text { Relative accumulation } \\
\text { ( } \% \text { of control) }\end{array}$ \\
\hline Control & & 100 \\
\hline Cyclosporin A & 17 & $445 \pm 18.9 * * *$ \\
\hline \multirow{3}{*}{ Capsaicin } & 1 & $108 \pm 2.4$ \\
\hline & 10 & $105 \pm 3.2$ \\
\hline & 100 & $144 \pm 3.4^{* *}$ \\
\hline \multirow[t]{5}{*}{ Piperine } & 1 & $90.8 \pm 1.8$ \\
\hline & 10 & $94.5 \pm 3.8$ \\
\hline & 30 & $152 \pm 3.8^{*}$ \\
\hline & 100 & $163 \pm 1.2 * *$ \\
\hline & 300 & $234 \pm 23.7 *$ \\
\hline \multirow[t]{3}{*}{ Sesamin } & 1 & $86.8 \pm 2.3$ \\
\hline & 10 & $88.2 \pm 0.5$ \\
\hline & 100 & $221 \pm 7.3 * *$ \\
\hline \multirow[t]{3}{*}{ Daidzein } & 1 & $97.5 \pm 3.2$ \\
\hline & 10 & $84.1 \pm 1.9 * *$ \\
\hline & 100 & $70.7 \pm 2.1 * *$ \\
\hline \multirow[t]{3}{*}{ Genistein } & 1 & $90.6 \pm 0.7$ \\
\hline & 10 & $76.7 \pm 2.2 * *$ \\
\hline & 100 & $91.4 \pm 3.2$ \\
\hline \multirow[t]{2}{*}{ Curcumin } & 1 & $115 \pm 4.3$ \\
\hline & 10 & $115 \pm 8.0$ \\
\hline \multirow[t]{3}{*}{ Taurine } & 1 & $131 \pm 13.3$ \\
\hline & 10 & $145 \pm 16.9$ \\
\hline & 100 & $141 \pm 22.9$ \\
\hline
\end{tabular}

Uptake of rhodamine $123(10 \mu \mathrm{M})$ was measured for $60 \mathrm{~min}$ at $37^{\circ} \mathrm{C}$ in $\mathrm{HBSS}$ containing a test compound. Each experiment was performed in parallel with a control in the absence of test compounds (taken as $100 \%$ ). Each value represents the mean \pm S.E. of three to six experiments. Asterisks show a significant difference from control values, $* p<0.05, * * p<0.01, * * * p<0.001$

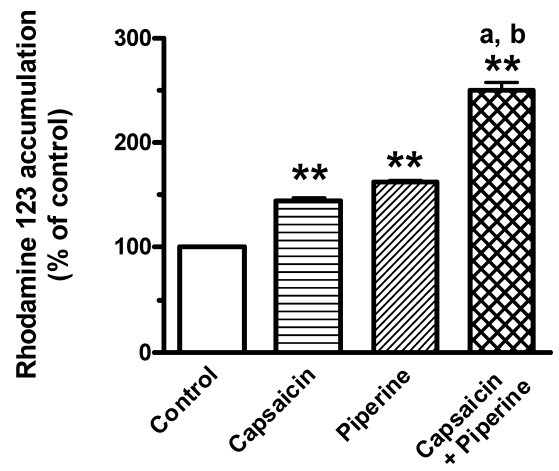

Fig. 2. Effects of Capsaicin, Piperine and a Mixture of the Two on Rhodamine 123's Accumulation in LS-180V Cells

The cells were incubated with rhodamine $123(10 \mu \mathrm{M})$ at $37^{\circ} \mathrm{C}$ for $60 \mathrm{~min}$ in the absence (control) or presence of capsaicin $(100 \mu \mathrm{M})$, piperine $(100 \mu \mathrm{M})$, and a mixture of the two $(50 \mu \mathrm{m}$ capsaicin $+50 \mu \mathrm{M}$ piperine $)$. Control: in the absence of test compounds. Each column represents the mean \pm S.E. for three to six experiments. $* * p<0.01 v s$. control, ${ }^{\mathrm{a}} p<0.01$ vs. capsaicin, ${ }^{\mathrm{b}} p<0.01$ vs. piperine.

1). The concurrent addition of piperine $(50 \mu \mathrm{M})$ and capsaicin $(50 \mu \mathrm{M})$ increased rhodamine 123 's accumulation by approximately 2.5 -fold, and the combined effect was significantly greater than the effect of either agent alone at a concentration of $100 \mu \mathrm{M}$ (capsaicin: 1.4-fold; piperine: 1.6-fold) (Fig. 2). On the other hand, the level of rhodamine 123 decreased significantly $(16-29 \%)$ in the presence of daidzein $(10,100$ $\mu \mathrm{M})$ and genistein $(10 \mu \mathrm{M})$ (Table 1).

We further examined the effects of dietary ingredients on the P-glycoprotein-mediated efflux of rhodamine 123 in LS$180 \mathrm{~V}$ cells. The efflux was significantly inhibited $(72 \%)$ by cyclosporin A (17 $\mu \mathrm{M})$ compared with the control, but signifi-

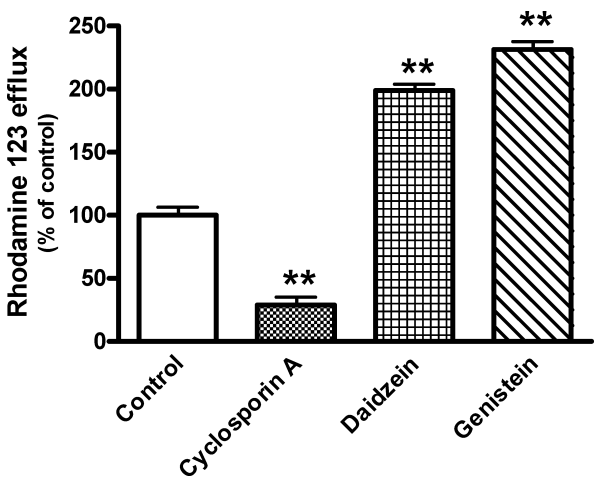

Fig. 3. Effects of Daidzein and Genistein on Rhodamine 123's Efflux from LS-180V Cells

The cells were incubated with rhodamine $123(10 \mu \mathrm{M})$ at $37^{\circ} \mathrm{C}$ for $60 \mathrm{~min}$, washed with HBSS, and incubated with rhodamine 123 -free $\mathrm{HBSS}$ at $37^{\circ} \mathrm{C}$ for $60 \mathrm{~min}$ in the absence (control) or presence of cyclosporin A $(17 \mu \mathrm{M})$, daidzein $(100 \mu \mathrm{M})$, and genistein $(100 \mu \mathrm{M})$. Control: in the absence of test compounds. Each column represents the mean \pm S.E. for three to six experiments. $* * p<0.01 v s$. control.

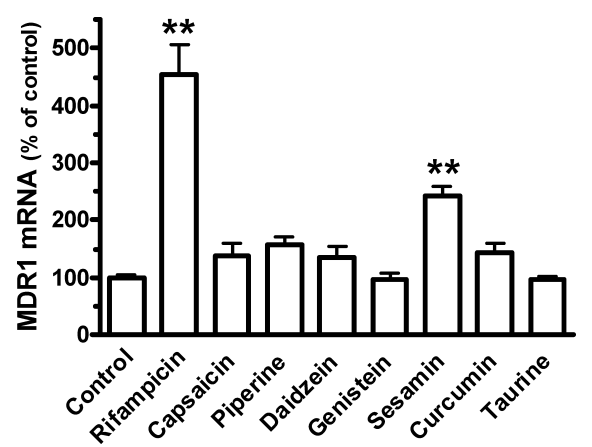

Fig. 4. Effects of Pretreatment with Dietary Ingredients on MDR1 mRNA Levels in LS-180V Cells

The cells were pretreated with rifampicin $(10 \mu \mathrm{M})$, capsaicin $(100 \mu \mathrm{M})$, piperine $(300 \mu \mathrm{M})$, daidzein $(100 \mu \mathrm{M})$, genistein $(100 \mu \mathrm{M})$, sesamin $(10 \mu \mathrm{M})$, curcumin $(10 \mu \mathrm{M})$, or taurine $(100 \mu \mathrm{M})$ for $48 \mathrm{~h}$. The control was incubated in the absence of test compounds. Total RNA was isolated from these cells and the level of MDR1 mRNA was measured by quantitative RT-PCR. The level was normalized with that of $\beta$-actin mRNA. Each column represents the mean \pm S.E. for three to nine experiments. $* * p<$ $0.01 v s$. control.

cantly increased (2.0- and 2.3-fold, respectively) in the presence of daidzein $(100 \mu \mathrm{M})$ and genistein $(100 \mu \mathrm{M})$ (Fig. 3). Curcumin $(1,10 \mu \mathrm{M})$ and taurine $(1-100 \mu \mathrm{M})$ tended to increase the amount of rhodamine 123 but the effect was statistically insignificant and not concentration-dependent (Table 1).

Effects of Pretreatment with Dietary Ingredients on the Expression and Function of P-Glycoprotein in LS-180V Cells After the pretreatment of LS-180V cells with dietary ingredients for $48 \mathrm{~h}$, the expression of P-glycoprotein (MDR1) mRNA was determined by real-time PCR. MDR1 mRNA was increased by 4.5 - and 2.4-fold, respectively, after 48-h pretreatment with rifampicin $(10 \mu \mathrm{M})$ and sesamin (10 $\mu \mathrm{M})$ (Fig. 4). Also, expression level of P-glycoprotein was significantly increased (2.0-fold) after treatment with rifampicin $(10 \mu \mathrm{M}$, for $48 \mathrm{~h})$ and tended to increase in the presence of capsaicin $(100 \mu \mathrm{M})$, daidzein $(100 \mu \mathrm{M})$, genistein $(100 \mu \mathrm{M})$ or sesamin $(10 \mu \mathrm{M})$ (Fig. 5). The amount of rhodamine 123 was significantly decreased (24\%) after pretreatment with rifampicin $(10 \mu \mathrm{M}, 48 \mathrm{~h})$ (Table 2). Pretreatment with piperine $(10-300 \mu \mathrm{M})$, genistein $(10 \mu \mathrm{M})$ or curcumin $(1,10 \mu \mathrm{M})$ reduced significantly $(12-19 \%)$ rhodamine 123 levels while treatment with capsaicin, sesamin, daidzein or 


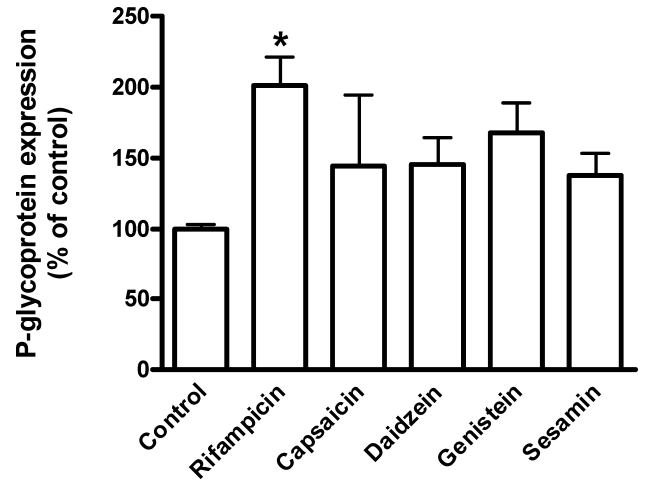

Fig. 5. Effects of Pretreatment with Dietary Ingredients on P-Glycoprotein Expression Levels in LS-180V Cells

The cells were pretreated with rifampicin $(10 \mu \mathrm{M})$, capsaicin $(100 \mu \mathrm{M})$, daidzein $(100 \mu \mathrm{M})$, genistein $(100 \mu \mathrm{M})$, or sesamin $(10 \mu \mathrm{M})$ for $48 \mathrm{~h}$. The control was incubated in the absence of test compounds. A membrane fraction was prepared from these cells and P-glycoprotein expression was determined by Western blotting and quantified by densitometry. Each column represents the mean \pm S.E. for three experiments. $* p<0.05 v s$. control.

Table 2. Effects of Pretreatment with Dietary Ingredients on Rhodamine 123 's Accumulation in LS-180V Cells

\begin{tabular}{|c|c|c|}
\hline & $\begin{array}{l}\text { Concentration } \\
\qquad(\mu \mathrm{M})\end{array}$ & $\begin{array}{l}\text { Relative accumulation } \\
\quad(\% \text { of control })\end{array}$ \\
\hline Control & & 100 \\
\hline Rifampicin & 10 & $76.1 \pm 2.4 * *$ \\
\hline \multirow[t]{3}{*}{ Capsaicin } & 1 & $92.7 \pm 2.8$ \\
\hline & 10 & $97.4 \pm 8.3$ \\
\hline & 100 & $87.4 \pm 2.1$ \\
\hline \multirow[t]{4}{*}{ Piperine } & 1 & $93.5 \pm 3.6$ \\
\hline & 10 & $87.9 \pm 1.7 *$ \\
\hline & 100 & $88.1 \pm 1.0 * *$ \\
\hline & 300 & $81.3 \pm 1.9 * *$ \\
\hline \multirow[t]{3}{*}{ Sesamin } & 1 & $107 \pm 6.1$ \\
\hline & 10 & $98.4 \pm 4.1$ \\
\hline & 100 & $96.4 \pm 2.2$ \\
\hline \multirow[t]{3}{*}{ Daidzein } & 1 & $92.5 \pm 3.7$ \\
\hline & 10 & $90.4 \pm 3.6$ \\
\hline & 100 & $93.0 \pm 3.4$ \\
\hline \multirow[t]{2}{*}{ Genistein } & 1 & $88.6 \pm 1.7$ \\
\hline & 10 & $88.4 \pm 4.5^{* *}$ \\
\hline \multirow[t]{2}{*}{ Curcumin } & 1 & $85.9 \pm 4.9^{*}$ \\
\hline & 10 & $87.5 \pm 3.0 *$ \\
\hline \multirow[t]{3}{*}{ Taurine } & 1 & $93.8 \pm 3.3$ \\
\hline & 10 & $97.6 \pm 3.9$ \\
\hline & 100 & $92.5 \pm 3.2$ \\
\hline
\end{tabular}

The cells were pretreated with a test compound for $48 \mathrm{~h}$, then uptake of rhodamine $123(10 \mu \mathrm{M})$ was measured for $60 \mathrm{~min}$ at $37^{\circ} \mathrm{C}$ in HBSS. Each experiment was performed in parallel with a control in the absence of test compounds (taken as $100 \%$ ). Each value represents the mean \pm S.E. of three to six experiments. Asterisks show a significant difference from control values, $* p<0.05, * * p<0.01$.

taurine had little effect on the accumulation (Table 2). Thus, these results suggest that rifampicin increased MDR1 gene transcription, P-glycoprotein expression, and the efflux of rhodamine 123 , whereas piperine, genistein and curcumin enhanced the P-glycoprotein-mediated efflux without altering the expression of MDR1 mRNA or P-glycoprotein.

Effects of Pretreatment with Dietary Ingredients on the Gene Expression of MRPs in LS-180V Cells LS-180V cells were pretreated with each dietary ingredient for $48 \mathrm{~h}$ and the mRNA expression of MRP1, MRP2 and MRP3 was measured. MRP1 mRNA levels in LS-180V cells were significantly increased (2.2- and 1.8-fold, respectively) by the
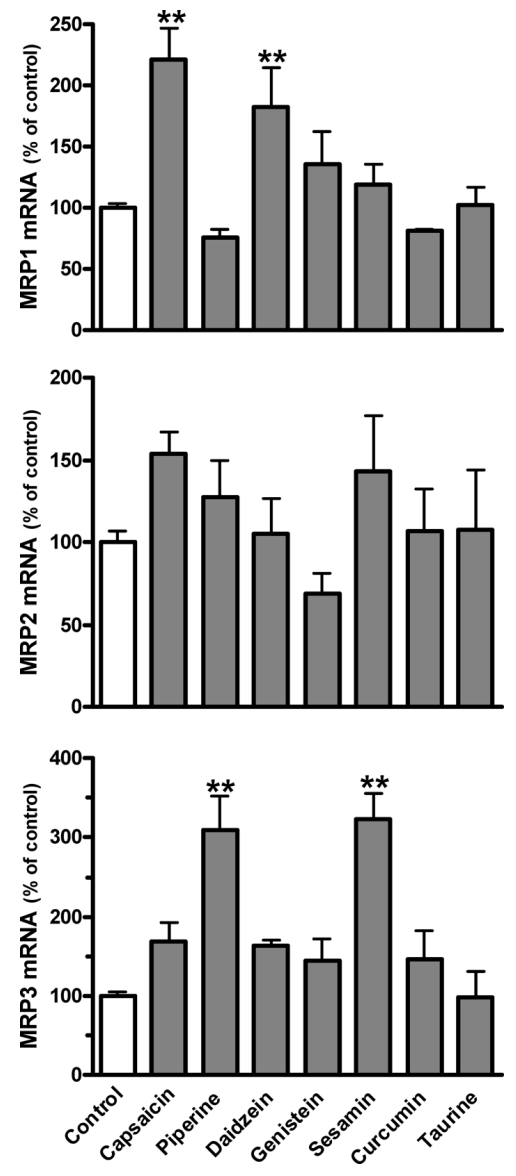

Fig. 6. Effects of Pretreatment with Dietary Ingredients on mRNA Levels of MRP1, MRP2, and MRP3 in LS-180V Cells

The cells were pretreated with capsaicin $(100 \mu \mathrm{M})$, piperine $(300 \mu \mathrm{M})$, daidzein $(100 \mu \mathrm{M})$, genistein $(100 \mu \mathrm{M})$, sesamin $(10 \mu \mathrm{M})$, curcumin $(10 \mu \mathrm{M})$, or taurine $(100 \mu \mathrm{M})$ for $48 \mathrm{~h}$. The control was incubated in the absence of test compounds. Total RNA was isolated from these cells and the level of MRP mRNA was measured by quantitative RT-PCR. The level was normalized with that of $\beta$-actin mRNA. Each column represents the mean \pm S.E. for three experiments. $* * p<0.01 v s$. control.

treatment with capsaicin $(100 \mu \mathrm{M})$ or daidzein $(100 \mu \mathrm{M})$ (Fig. 6). MRP2 mRNA levels were not significantly affected by treatment with any of the ingredients tested. MRP3 mRNA levels were increased significantly (3.1- and 3.2-fold, respectively) by treatment with piperine $(300 \mu \mathrm{M})$ or sesamin $(10 \mu \mathrm{M})$.

\section{DISCUSSION}

The current study was undertaken to investigate the effects of dietary ingredients (piperine, capsaicin, daidzein, genistein, sesamin, curcumin, and taurine) (Fig. 1) on the expression of mRNA and protein and on the function of P-glycoprotein, by using LS- $180 \mathrm{~V}$ cells. LS-180 cells are frequently employed as an intestinal model for the analysis of transcriptional modulation, ${ }^{12)}$ but are not suitable for a functional analysis of P-glycoprotein. Thus, we used LS-180V cells derived from LS-180 by stepwise selection in vinblastine, ${ }^{11)}$ for the simultaneous analysis of transcriptional and functional modulation. It was confirmed that cyclosporin A, a P-glycoprotein inhibitor, promoted significantly the accumulation of rhodamine 123, a substrate of P-glycoprotein, in these cells and attenuated the efflux of rhodamine 123. 
The effects of seven dietary ingredients on P-glycoprotein function were examined by measuring the accumulation and efflux of rhodamine 123 in LS-180V cells. Capsaicin, piperine and sesamin increased the amount of rhodamine $123 \mathrm{ac}-$ cumulated in LS-180V cells, whereas daidzein and genistein stimulated the efflux of rhodamine 123 (Table 1, Fig. 3). These results suggest that the P-glycoprotein-mediated efflux is inhibited by piperine, capsaicin and sesamin while it is stimulated by daidzein and genistein. Consistent with this observation, it was reported that piperine and capsaicin inhibited P-glycoprotein-mediated efflux in Caco-2 and KB-C2 cells. ${ }^{7,8)}$ Notably, the concurrent addition of piperine and capsaicin seemed to exert a more-than-additive inhibitory effect (Fig. 2). Thus, it is speculated that mixtures of dietary ingredients inhibit synergistically P-glycoprotein-mediated efflux at relatively low concentrations.

Next, the effects of pretreatment with the test compounds on the expression and function of P-glycoprotein in LS-180V cells were examined. Pretreatment with rifampicin increased P-glycoprotein (MDR1) mRNA expression by 4.5 -fold and its protein expression by 2.0 -fold, indicating that the rifampicin treatment induced P-glycoprotein expression in LS$180 \mathrm{~V}$ cells. Sesamin caused a 2.4-fold increase in MDR1 mRNA expression (Fig. 4), but had little significant effect on P-glycoprotein expression (Fig. 5) or accumulation of rhodamine 123 (Table 2). Piperine, capsaicin, daidzein, genistein, curcumin and taurine had little significant effect on the expression of MDR1 mRNA or P-glycoprotein, suggesting that they did not cause transcriptional modulation of P-glycoprotein. Piperine, genistein and curcumin, however, reduced the accumulation of rhodamine 123. Thus, these ingredients may stimulate P-glycoprotein-mediated efflux without increasing P-glycoprotein expression. The reason for this apparent discrepancy is unknown, but it was also reported that pretreatment of Caco- 2 cells with morphine enhanced P-glycoprotein-mediated efflux without the induction of MDR1 mRNA. ${ }^{17)}$ Further experiments on posttranscriptional regulation of P-glycoprotein are required.

In addition to P-glycoprotein, MRPs are functionally expressed at intestinal epithelia. ${ }^{6}$ In LS-180V cells, significant increases in mRNA expression were observed for MRP1 (2.2- and 1.8-fold, respectively) on pretreatment with capsaicin and daidzein and for MRP3 (3.1- and 3.2-fold, respectively) on pretreatment with piperine and sesamin, but the compounds tested had little significant effect on the expression of MRP2 (Fig. 6). MRP1 and MRP3 have been shown to transport anionic drugs including methotrexate and etoposide. ${ }^{18,19)}$ Little information is available about the effects of dietary ingredients on the transport functions of MRPs. The observed induction of MRP1 expression by capsaicin and daidzein and of MRP3 expression by piperine and sesamin, raises the possibility that repeated exposure to these dietary ingredients might affect the intestinal absorption of anionic drugs. In addition to the intestinal transporters, it is of interest that breast cancer resistance protein (BCRP) modulates the distribution of daidzein and genistein in the brain. ${ }^{20)}$

In conclusion, our results suggest that P-glycoprotein-mediated efflux is inhibited by capsaicin, piperine and sesamin while it is stimulated by daidzein and genistein. Also, capsaicin, daidzein, piperine and sesamin increased significantly the mRNA expression of MRP1 or MRP3. Thus, the present study provides further evidence that repeated exposure to dietary ingredients can cause drug-food interactions by affecting the function and mRNA expression of intestinal transporters such as P-glycoprotein.

Acknowledgments This work was supported by Grantsin-Aid from Food Safety Commission, Japan (No. 0807).

\section{REFERENCES AND NOTES}

1) Present address: Department of Drug Disposition and Pharmacokinetics, Teikyo University School of Pharmaceutical Sciences; 1091-1 Suarashi, Sagamiko, Sagamihara, Kanagawa 229-0195, Japan.

2) Bailey D. G., Spence J. D., Munoz C., Arnold J. M., Lancet, 337, 268-269 (1991).

3) Nowack R., Andrassy J., Fischereder M., Unger M., Clin. Pharmacol. Ther., 85, 439-443 (2009).

4) Aszalos A., Curr. Drug Metab., 9, 1010-1018 (2008).

5) Tsuji A., Tamai I., Pharm. Res., 13, 963-977 (1996).

6) Borst P., Evers R., Kool M., Wijnholds J., J. Natl. Cancer Inst., 92, 1295-1302 (2000)

7) Bhardwaj R. K., Glaeser H., Becquemont L., Klotz U., Gupta S. K., Fromm M.F., J. Pharmacol. Exp. Ther, 302, 645-650 (2002).

8) Nabekura T., Kamiyama S., Kitagawa S., Biochem. Biophys. Res. Commun., 327, 866-870 (2005).

9) Anuchapreeda S., Leechanachai P., Smith M. M., Ambudkar S. V., Limtrakul P. N., Biochem. Pharmacol., 64, 573-582 (2002).

10) Hou X. L., Takahashi K., Tanaka K., Tougou K., Qiu F., Komatsu K., Takahashi K., Azuma J., Int. J. Pharm., 358, 224-229 (2008).

11) Herzog C. E., Tsokos M., Bates S. E., Fojo A. T., J. Biol. Chem., 268, 2946-2952 (1993).

12) Synold T. W., Dussault I., Forman B. M., Nat. Med., 7, 584-590 (2001).

13) Fontaine M., Elmquist W. F., Miller D. W., Life Sci., 59, 1521-1531 (1996).

14) Takara K., Tsujimoto M., Ohnishi N., Yokoyama T., Biochem. Biophys. Res. Commun., 292, 190-194 (2002).

15) Li Q., Sai Y., Kato Y., Tamai I., Tsuji A., Pharm Res., 7, 584-590 (2003).

16) Sai Y., Nies A. T., Arias I. M., J. Cell Sci., 112, 4535-4545 (1999).

17) Okura T., Ozawa T., Ito Y., Kimura M., Kagawa Y., Yamada S., Biol. Pharm. Bull., 31, 2338-2341 (2008).

18) Zeng H., Chen Z. S., Belinsky M. G., Rea P. A., Kruh G. D., Cancer Res., 61, 7225-7232 (2001).

19) Kool M., van der Linden M., de Haas M., Scheffer G. L., de Vree J. M., Smith A. J., Jansen G., Peters G. J., Ponne N., Scheper R. J., Elferink R. P., Baas F., Borst P., Proc. Natl. Acad. Sci. U.S.A., 96, 6914-6919 (1999).

20) Enokizono J., Kusuhara H., Sugiyama Y., Mol. Pharmacol., 72, 967 975 (2007). 